\title{
Actinic cheilitis: A case report and a review of the literature
}

Dasaiev M. Dutra ${ }^{a}$, Maria Auxiliadora G do Nascimento ${ }^{a}$, Maria Sueli Marques Soares ${ }^{b}$

\section{ABSTRACT}

Objective: This article presents a case report of actinic cheilitis with an acute inflammatory process and need for anti-inflammatory treatment.

Case Report: Triamcinolone acetonide in Orabase was prescribed 3 times a day for 15 days, and the patient was advised to use sunscreen and hats. After 7 days, there was a significant improvement in the acute phase and the patient was kept under observation.

Conclusion: It is emphasized that it is important to intervene in the evolution of the inflammatory process in premalignant lesions in order to prevent its long-term maintenance.

Key words: Cheilitis; Carcinoma; Inflammation

\section{Queilite actínica: relato de caso e revisão da literatura}

\section{RESUMO}

Objetivo: O presente artigo apresenta um relato de queilite actínica com processo inflamatório agudo e necessidade de tratamento com anti-inflamatório

Relato do Caso: Foi prescrito acetonido de triancinolona em orabase, 3 vezes ao dia, durante 15 dias e orientou-se para uso de protetor solar e chapéu. Após 7 dias, houve melhora significativa do quadro agudo, permanecendo o paciente em proservação.

Conclusão: Ressalta-se que em lesões potencialmente malignas, torna-se importante interferir na evolução de processos inflamatórios, impedindo sua permanência por longo período de tempo.

Palavras-chave: Queilite; Carcinoma; Inflamação

\author{
a Postgraduation Program in Dentistry, Federal \\ University of Paraíba, João Pessoa, Brazil \\ ${ }^{\mathrm{b}}$ Department of Stomathology, Federal University \\ of Paraíba, João Pessoa, Brazil
}

Conflict of Interests: The authors state that there re no financial and personal conflicts of interest that could have inappropriately influenced their work.

Copyright: ( 2016 Dutra et al licensee EDIPUCRS 


\section{INTRODUCTION}

Actinic cheilitis (AC) is a potentially malignant lesion that can progress to squamous cell carcinoma [1]. The lesion affects the lips and is caused by the solar ultraviolet radiaton [2,3]. It predominantly involves the lower lip of Causasian men aged 50-60 years old [4] and is clinically characterized by changes in the color of the labial semimucosa (red, white, gray or brown areas), loss limits between the skin and semimucosa, fissures, dry and atrophic areas, in addition to lip erosion $[2,5,6]$.

In the acute form the AC, ulcer, blister and scab are present and regress after the exposure to the causative agent is ceased. On the other hand, the chronic form results from continuous and long-term sun exposure [7]. The presence of ulcers failing to heal, bleeding and hardened borders is suggestive of malignant transformation [8].

Histologically, AC is characterized by a stratified squamous epithelium with varied degrees of keratinization. There may also be varying degrees of epithelial atypia consisting of dysplasias ${ }^{4}$. Inflammation and solar elastosis are observed in the connective tissue [2,9]. The same lesion may show different histopathological types in different regions [10] and the degree of epithelial atypia may not reflect the biological potential of the lesion $[4,11]$. It is often not possible to associate clinical and histopathological aspects, thus the evolution of AC can not be determined only by clinical features [12]. Clinical and histopathological evaluations are very important to diagnose and/or treat AC. The diagnosis should be based on clinical and histopathological findings in addition to the history of sun exposure. Early diagnosis, preventive measures and treatment and clinical management of the injury are important to prevent malignant transformation.

Several treatments of $\mathrm{AC}$ are used aiming to remove or destruct the abnormal epithelium, including topical application of 5-fluorouracil, trichloroacetic acid, imiquimod, retinoids, vermilionectomy, $\mathrm{CO}_{2}$ laser vaporization, Er: YAG laser, cryosurgery, electrodessication and photodynamic therapy. All these treatments are destructive and cause discomfort to the patient, which contributes to the constant search for other therapeutic modalities. Topical antiinflammatories have been used as the prevention from malignant transformation in chronic lesions. They have also been used to alleviate the acute inflammatory reaction, which promotes more comfort to the patient $[14,15]$.

In geographic areas with a tropical weather, with high indices of solar radiation, such as the Northeastern Brazil, the occurrence of $\mathrm{AC}$ assumes greater importance so it is essential to widely diffuse the knowledge concerning the clinical aspects and evolution of the injury among dentists. The present article presents a literature review and description of a clinical case, and discuss the treatment of the injury.

\section{CASE DESCRIPTION}

A 73-year-old Caucasian male patient who worked as a farmer was attended at the Stomatology Clinic of the Federal University of Paraíba complaining about the presence of a "wounded lower lip". The patient reported that the lesion had a history of about 2 years and also that in the last 15 days there had been an increase in the size of the ulcerated area including burning and discomfort in talking, smiling and eating. On physical examination, fissures, crusting, edema, presence of hair and loss limits between the skin and semimucosa were observed in the lower lip (Figure 1). Based on clinical findings and the history of chronic sun exposure, a clinical diagnosis of actinic cheilitis was made. Triamcinolone acetonide in Orabase was prescribed 3 times a day for 15 days and the patient was advised to use sunscreen and hat. After 7 days, the patient returned to the clinics for evaluation and significant clinical improvement was registered. After 15 days, there was no sign of acute inflammation (Figure 2). After 9 months under observation, the lesion was clinically stable and the patient was instructed to return every six months for evaluation (Figure 3).

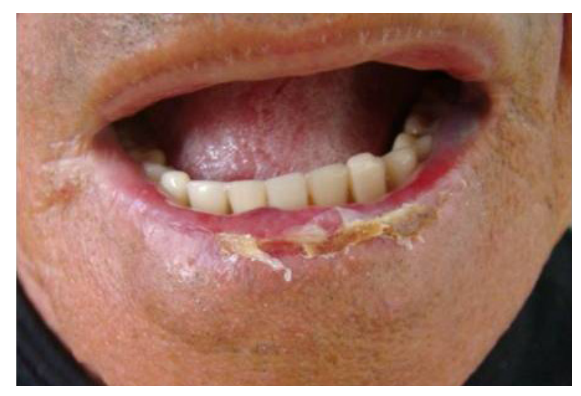

Figure 1. Clinical aspect of QA fissures, crusting, edema, and the presence of loss of the vermilion border of the lip skin.

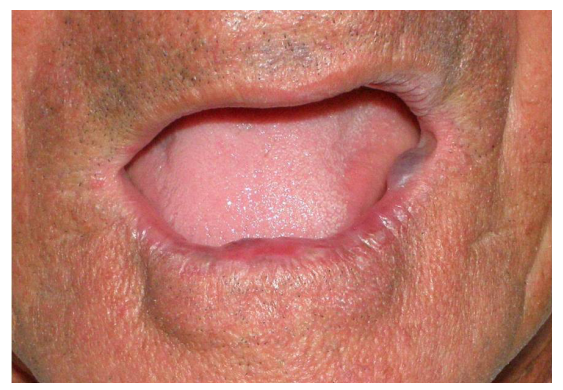

Figure 2. Clinical aspect of the AC medication after 15 days.

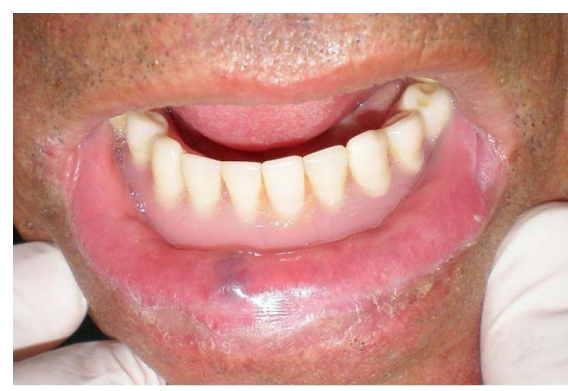

Figure 3. Clinical aspect of the AC after 9 months under observation. 


\section{DISCUSSION}

$\mathrm{AC}$ is caused by solar radiation. However, other factors such as smoking and infection with HPV may be associated with the development and the risk of malignant transformation of the lesion [16]. In the presented case, the smoker patient had a history of long exposure to solar radiation. Besides, he had old age and white skin, which are clinical characteristics often related to the occurrence of AC. These data corroborate the findings of other authors $[17,18]$.

Several authors emphasize the relationship between chronic inflammation and squamous carcinogenesis $[8,19]$ and consider the hypothesis that the mediators of the inflammatory process play an important role in the process of malignant transformation and progression of actinic cheilitis [20]. Thus, we believe that clinical follow-up of AC lesions is important for the control of acute inflammation caused by sun exposure, in order to eliminate or reduce the effect of these mediators of inflammation. In this case, the patient sought the service featuring an acute inflammation that emphasized the clinical aspects with painful symptoms, which caused much discomfort. Considering the symptoms presented, we decided to prescribe the topical antiinflammatory drug triamcinolone acetonide in emollient base for dental use, three times a day for 15 days, showing excellent response. Positive clinical success with the use of anti-inflammatory for the treatment of actinic cheilitis is reported in the literature by various authors $[14,15,21,22]$. The use of the non-steroidal anti-inflammatory drug diclofenac in the treatment and prevention of the malignization of actinic cheilitis is explained by the authors for its possible anticancer effect on inhibiting cyclooxygenase (COX-1 and COX-2) [23]. It is also important to remember that the oxidative stress caused by the inflammatory process can damage the cell DNA, that chronic inflammation increases the risk of carcinogenesis [24] and that inflammation may promote the progression from $\mathrm{AC}$ to squamous cell carcinoma [25].

Considering $\mathrm{AC}$ is a potentially malignant lesion and the importance of inflammation in epithelial carcinogenesis, the possibility of using anti-inflammatory drugs is highlighted not only as a treatment for reducing acute inflammation, but also as a prevention of chronic injuries. In this type of lesion, it is important to interfere in the evolution of the inflammatory process preventing long-term injuries.

\section{REFERENCES}

1. Domaneschi C, Santos SG, Navarro CM, Massucato SEM. Actinic cheilitis actinic association between radiation and trauma. RGO. 2003;51:101-4

2. Wood NH, Khammissa R, Meyerov R, Lemmer J, Feller L. Actinic cheilitis: a case report and a review of the literature. Eur J Dent. 2011;5:101-6.
3. Rossoe EWT, Tebcherani AJ, Sittart JA, Pires MC. Queilite actínica avaliação comparativa estética e funcional entre as vermelhectomias clássica e em W-plastia. An Bras Dermatol. 2011:86(1):65-73.

4. Martins MD, Marques LO, Martins MAT, Bussadori SK, Fernandes KPS, Kristianne PS. Queilite actínica: relato de caso clínico. ConScientiae Saúde. 2007;6:105-10.

5. Miranda AMO, Ferrari TM, Calandro TLL. Queilite actínica : aspectos clínicos e prevalência encontrados em uma população rural do interior do brasil. Revista Saúde e Pesquisa. 2011;4:67-72.

6. Savage NW, Mckay C, Faulkner C. Actinic cheilitis in dental practice. Aust Dent J. 2010;55:78-84

7. Kaugers GE, Pillon T, Svirsk J, Pages DG, Bruns JC. Actinic cheilitis: a review of 52 cases. Oral surg oral med oral pathol oral radiol oral endod. 1999; 88:181-6.

8. Mantovani A, Allavana P, Sica A, Balkwill F. Cancer- related inflammation Nature. 2008;454:436-44

9. Freitas MCA, Ramalho LMP, Xavier FCA, Moreira ALG, Reis SRA. p53 and mdm2 protein expression in actinic cheilitis. J Appl Oral Sci. 2008;16: 414-9.

10. Véo PCR, Farias RE, Stehling RSS, Urbano ES. Tratamento cirúrgico da queilose actínica RGO. 2010;58:393-7.

11. De Santana SDJ, Da Costa MMC, Queiroz LM, Godoy GP, Da Silveira EJ. Actinic cheilitis: clinicopathologic profile and association with degree of dysplasia. Int J Dermatol. 2014;53:466-72

12. Cavalcante AS, Anbinder AL, Carvalho YR. Actinic Cheilitis: Clinical and Histological Features. J Oral Maxillofac Surg. 2008;66:498-503.

13. Berking $C$, Herzinger T, Flaig MJ, Brenner M, Borelli C, Degitz K. The efficacy of photodynamic therapy in actinic cheilis of the lower lip; a prospective study of 15 patients. Dermatol Surgery. 2007;33:825-30.

14. Pirard D, Vereecken P, Mélot C, Heenen M. Three percent diclofenac in $2.5 \%$ hyaluronan gel in the treatment of actinic keratoses: a meta-analysis of the recent studies. Arch Dermatol Res. 2005;297:185-9.

15. Mehregan DR, Mehregan DA, Pakiden S. Cheilitis due to treatment with simvastin. Cutis. 1998:62:197-8.

16. Chiller KG, Washington C, Sober AJ, Koh HK. Cancer of the skin. In: Kasper DL et al., eds. Herrisons Principales of molecular medicine. $16^{\text {th }}$ ed. New York: McGraw-Hill. 2005;p.497-503

17. Jadotte YT, Schwartz RA. Solar Cheilosis: an onimous precursor: part I. Diagnostic insights. J Am Acad Dermatol. 2012;66:173-84.

18. Warnakulasuriya $S$, Johnson NW, Van der waal I. Nomenclature and classification of potentially malignant disorders of the oral mucosa. J Oral Pathol Med. 2007:36:575-80

19. Nickoloff BJ, Ben-neriah Y, Pikarsky E. Inflammation and cancer : is the link as simple as we think? J Invest Dermatol. 2005;124:1275-84

20. Rojas IG, Martinez A, Pineda A, Spencer ML, Jimenez M, Rudolph MI Increased mast cell density and portease content in actinic cheilitis. J Oral Pathol Med. 2004:33:567-73.

21. Lima GDS, Gomes AP, de Araújo LM, Salum FG. Diclofenac in hyaluronic acid gel: an alternative treatment for actinic cheilitis. J Appl Oral Sci. 2010 18:533-7.

22. Wolf JE, Taylor JR, Tschen E, Kang S. Topical 3.0\% diclofenac in 2.5\% hyaluronan gel in the treatment of actinic keratoses. Int $\mathrm{J}$ Dermatol. 2001:24: 709-13.

23. Fecker LF, Stockfleth E, NindI I, Ulrich C, Forschner T, Eberle J. The role of apoptosis in therapy and prophylaxis of epithelial tumours by nonsteroidal anti-inflammatory drugs (NSAIDs). Br J Dermatol. 2007;156 (Suppl 3): 25-33

24. Kawanishi S, Hiraku Y, Pinlaor S, Ma N. Oxidative and nitrative DNA damage in animals and patients with inflammatory diseases in relation to inflammation - related carcinogenesis. Biol Chem. 2006;387:365-72

25. Berhane T, Halliday GM, Cooke B, Barnetson RS. Inflammation is associated with progression of actinic keratoses to squamous cell carcinomas in humans. Br J Dermatol. 2002:146:810-5. 